\title{
Problems of Rural Settlement Network Formation
}

\author{
V.P. Riabokon ${ }^{1}$ \\ ${ }^{1}$ Doctor of Economics, Professor, Academician of NAAS
}

\begin{abstract}
The Ukrainian village, characterized by the territorial settlement of the indigenous population with a reflection of certain features of social and living conditions and traditions, acts as the socio-organizational form of the historical origin, formation and development of the peasantry under the influence of significant changes in the assembly of many natural and social factors. The overwhelming majority of the villagers live separately in their own family buildings in the rural settlement network.
\end{abstract}

Keywords:The Ukrainian ,socio-economic ,economic,Ukrainian, rural ,employees.

\section{Introduction}

Formation of a stable rural settlement network, socio-economic conditions of its development together with organizational and technological peculiarities of agrarian production, in which the land acts as the main means and the combination of agricultural crops and species of productive animals serve as subject of labour, create a specific way of life of the rural population based at the core of the organization of agrarian production, as a sector of the national economic complex.

\section{The results}

In recent years the Ukrainian village has undergone significant changes due to structural economic reforms: the restructuring of land and property relations, the creation of a legal framework for a market economy through the privatization of land, property and the use of individual and family as well as collective labor. However, during the reforms primary attention was paid to the development of agricultural production and the corresponding industrial relations, while the issues of creation and development of rural settlement network were given a secondary role by the residual principle. Ultimately, this led to a decline in the countryside, characterized by depopulation, negative demographic situation, rising unemployment, and the destruction of the social sphere.

Under current conditions problems of rural areas development can only be solved by introducing effective state policy. One of the policies is directed at decentralization of power, creation and organization of rural joint territorial communities functioning. The further development of the rural settlement network largely depends on the success of these processes.

The rural settlement network is spread across the territory of Ukraine, where one third of the country`s total population permanently resides. As of the beginning of 2017, the rural settlement network comprised 28,377 rural settlements - house to 5 million 602 thousand economically active population making up 43,1\%, including 5,1 million of employed persons.

Among the latter, 68,9\% are employees, 28,9\% are self-employed, and 1,3\% are employers and working for free family members. Over the period 2000-2017, the number of hired workers in agriculture decreased from 2,8 million to 497,8 thousand people. One of the important factors influencing employment is the availability of business entities in rural areas, while in $34,2 \%$ of settlements they are absent.

For a long period Ukraine has been witnessing the decline of its villages and the deterioration of the demographic situation. Every year rural settlements disappear from the map of Ukraine. Only from 1991 to 2017 the number of rural settlements decreased by 468 units. Out of the total number of rural settlements in 2001 there were 151 depopulated and deregistered units, in $2005-227$; in $2013-369$.

According to the research conducted by the State Statistics Service, by the beginning of 2014 the number of rural settlements with a population of more than 500 people decreased by 7,2 \% (compared with 1991), 17,3\% of rural settlements had up to 50 inhabitants in each of them, in almost 2,5 thousands of rural settlements more than $50 \%$ of the population were in their sixties and older. And out of all rural residents $22,8 \%$ were aged 60 years and older, and only $18,9 \%$ were children under the age of 18 . As of January 1, 2018 the rural population amounted to 13,0 million people 
making up 31,0 \% of the total population. From 1991 to 2017 the number of rural population decreased by almost 4 million people, or by $23,5 \%$, and in terms of one rural settlement - by $16,1 \%$.

The process of decrease in rural population, its productive part, reduction of the quantitative composition of the rural settlement network is historical, and these changes are to some extent an objective socio-economic phenomenon. After all, the village population is aging, its age and gender structure are deforming, depopulation processes are increasing with no growth of the rural population. Being abandoned the social sphere of rural areas practically does not develop due to the lack of necessary funds.

In addition, unemployment, constant rise in prices and utility tariffs, low wages and pensions erode the purchasing power of rural residents, with the cost of living constantly augmenting. The living standard of the villagers is deteriorating, most families do not earn subsistence' level income and are on the breadline. In 2017, with a significant increase in the average monthly salary in agriculture, it amounted to $5761 \mathrm{UAH}$, or 81,1\% of the total salary in economy, $75,5 \%$ - in industry sector, $92,1 \%$ - in construction, $74,9 \%$ - in transport sector, $75,5 \%$ - in trade, $44,7 \%$ of salaries in financial and insurance activities.

Over the past five years household incomes have subsided by $18 \%$, the social gas and electricity consumption norm has significantly decreased for government aid holders, in the end of 2018 the gas price for households has increased by 9 times icompared to 2013. According to statistics for January-November 2,23 billion UAH were paid as reimbursement of expenses for utility services payment. For 10 months, the number of families receiving subsidies has decreased by $52,6 \%$. According to the UN, more than $60 \%$ of Ukrainians live below the poverty line, while in fact their number is much bigger. Ukraine is on the last place in Europe for the living standard of the population. State measures to combat poverty have not yet yielded tangible results. In this regard, the experience of China, which focuses on targeted assistance to the poor or the eradication of poverty - "whom to help" and "how to help", is an interesting example. In just five years (2012-2017), the total number of the poor decreased by 70 million persons, it means, every minute the number of poor people became samller by 26 persons, the coefficient of poverty orrurence decreased from 10,2 to $3,1 \%$ [36].

Lower living standards, in particular, rural residents, unemployment and a number of other factors accelerate migration processes, and the economically active part of the population who has the appropriate education and training leaves from the village. According to unofficial data, for the period of independence, up to 10 million people left Ukraine to work in other countries. According to the information from the former Minister of Social Policy, there are 3,2 million of Ukrainian migrant workers who live permanently aborad, and from 8 to 9 million people who work there temporarily. Only in Poland there are about 2 million Ukrainians who live, study and work there.

If for 2012-2015 among EU non-citizens, the number of issued rights to permanent residence (RPR) increased by $20 \%$, or by 2,6 million units, then among Ukrainians - by 3,2 times, up to 500 thousand. Ukrainians are already entering in top 5 recipients of RPR or citizenship in 10 out of 28 EU countries. During this period, our citizens took the first place in the EU on the issued RPR, and moved from 21 to 8 place on obtaining citizenship [9]. According to the sociological group "Rating", $35 \%$ of our compatriots want to leave Ukraine forever, and among the youth aged 18-35, $54 \%$ would go to a permanent place of residence abroad. Also, among those who want to move to another country, there is a significantly higher percentage of people with higher education and high levels of prosperity than those who intend to stay. There is a concern about the mood of schoolchildren, a significant part of which relates their future to working abroad. Surveys conducted by the Institute of Sociology have shown that most people are afraid of rising prices $-81 \%$, non-payment of salaries and pensions $-60 \%$, unemployment $-73 \%$ [35].

According to a recent study by international headquarters portal Head Huntez, $92 \%$ of Ukrainians are ready to work abroad. The main motives for $58 \%$ of them are high salaries, and for $37 \%$ - it is a lack of decent work in the region. And $65 \%$ of respondents are ready not to work within their specialty, and more than $30 \%$ - on lower positions than at home. Foreign employers offer to workers up to seven and more Ukrainian salaries per month. At the same time, in addition to salaries of 2 thousand US dollars, a free accommodation is provided to visiting workers. In 2017, OLX published proposals for work in three dozen countries, where $77 \%$ of all vacancies fell to Poland. In December 2018, compared to the same period in 2017, the number of job offers in Germany increased by $13 \%$, where programmers, builders, retailers, workers and physicians were moving from Ukraine. It should be noted that $44 \%$ of vacancies from all proposals for Ukrainians are IT specialists.

Hence, in general, among those who want to leave, queries of economic orientation prevail. In 2017 labor migrants transferred in Ukraine 9,3 billion US dollars through international payment systems. Also, according to various estimates, they brought 4-5 billion US dollars in cash. Characteristically, this figure actually coincided in 10 months of 2018 with the profit from all export sales of agri-food products (USD 14,4 billion) [35].

Undoubtedly, the mass migration of able-bodied skilled workers abroad has a negative impact on the further development of the domestic economy. Already, for Ukraine, this became a serious threat, if the number of able-bodied 
population continues to decline. Therefore, the priority task for the state is to take measures to increase wages for the workers, create competitive jobs, and also to find additional motivational factors that would reduce the outflow of personnel at all levels.

This applies directly to the agrarian sector, as, as already noted, the number of rural population decreases year by year, villages die, the most productive part of the labor force is expelled from the rural settlement network.

At the same time, the peasantry traditionally occupied and occupies a very important place, during the centuries-old historical development of civilized social life, as the oldest community, directly related to agricultural production. His work activity plays an important role in the sustainable creation of food resources to meet the needs of the country's population, guaranteeing its food security in the global marketplace.

At the present stage, the provision of food products to the population of both Ukraine and other countries is a priority task of every nation to prevent the negative consequences of the global food crisis, which, along with the deepening of the energy and financial crises, becomes more and more acute.

The food crisis has become a phenomenon of a resonant nature in the planetary development of social existence, rather - a systemic strengthening of the rigidity of various conditions, closely linked to the process of reproduction of food resources to ensure the supplis to growing world population. The situation in the world with food is also directly related to Ukraine. On one hand, the food crisis has not blew over our country, and on the other hand, there are real opportunities for Ukraine to increase the production and export of grain in particular. In 2018 the harvest of grain reached almost 70,1 million tons. In general, economically, 70 million tons - it is $12 \%$ of GDP, 15 billion US dollars according to average world grain prices, more than $80 \%$ of gold reserves, as well as $40 \%$ of export earnings [9]. According to domestic and international experts, with the appropriate investment in the future, grain harvest can be increased to 80 million tons or more, thereby becoming important food supplier to the world market.

During the time of Ukraine's independence in the agro-industrial sector as a result of the structural economic reforms, the foundations of social and economic changes in property relations, the formation of a multi-faceted economy, the development of the democratization of economic activity, and the transition to a socially oriented market economy were laid.

Deep transformations in land relations have been made, privatization of agricultural land has been completed, stock and reserve lands have been formed. 5,6 million hectares of agricultural land have been transferred to private ownership and use of citizens for the management of a private farm, 4,44 million hectares -for farming, per one rural inhabitant there are 3,24 hectares of agricultural land and 2,46 hectares of arable land.

On the basis of reformed collective farms, private-leasing farms, agricultural enterprises, peasant (farmer's) farms and other organizational-legal structures were created.

The agrarian sector, which covers agriculture, food and processing industry, accounts for $45 \%$ of the state's economy; it accounts for almost three-quarters of the retail turnover, 10,2 \% of gross domestic product. Every year, 30 $\%$ of the consolidated budget of the country is created here, $41 \%$ is export of agri-food products, every second dollar of currency proceeds comes from the agrarian sector.

Under the influence of a complex of organizational and economic factors and a number of other factors, in the country priority is given to the primary development of the production sphere, creation of conditions for increasing volumes and increasing the efficiency of agro-industrial production. And this is natural, since the performance of the agrarian economy has a significant impact on the development of other sectors of the national economic complex.

However, due to the mistakes made in carrying out the agrarian reform, the violation of the interdepartmental equivalent exchange, the deepening of the disparity in prices for industrial and agricultural products, there has been a steady trend in negative processes, which led to a significant decrease in the solvency of the population and resulted in a significant decrease in the consumption of basic foodstuffs, its transition beyond the minimum physiological norms. More than half of the family budget $(58,9 \%)$ of rural households is spent on food products. In average, rural residents underconsumped $3,1 \mathrm{~kg}$ of meat and meat products, $167 \mathrm{~kg}$ of milk and dairy products, 2,8 $\mathrm{kg}$ of fruit. From 1990 to 2016 , the annual consumption of meat per person decreased by $24,7 \%$, milk - by $43,9 \%$, fish and fish products - by $45,2 \%$. The Ukrainian minimum zliving wage is three times lower than the UN standard of poverty.

At the same time, the curtailment of state regulation of the market environment, a sharp weakening of state control functions in providing material and technical resources of agricultural production led to a significant reduction in its efficiency, social tension in the countryside has sharpened.

In fact, the systemic restoration of the utilized means in the social sphere of the village was suspended, for the development of which funds are allocated on a residual basis. Thus, the State target program for 2015 it was planned to take measures for the development of the social sphere of rural settlements, in particular, the task was to save rural settlements and provide them with objects of social infrastructure. In fact, only $12,4 \%$ of the planned rural development 
funds were allocated, including housing and communal services $-11,2 \%$, education $-59,2 \%$, medicine - less $1 \%$, motorways $-6,2 \%$.

Over the period from 2000 to 2016, the number of secondary schools dropped by $25 \%$, the number of pupils - by $47,4 \%$, and the number of pupils at the rate of 10 thousand people - by $35,8 \%$. The number of cultural institutions and libraries decreased by 2,2 thousand, respectively.

In 2016, compared to 1990 , only $17,7 \%$ of housing was put into operation, $9,7 \%$ - preschool institutions, 2,1 - places for students, 12,8 - beds in hospitals, 2,6\% - places in institutions culture.

\section{Conclusions}

Taking into account the existing situation in the social sphere the Verkhovna Rada of Ukraine adopted the relevant legislative acts, in particular on the reform of education, medicine, and the pension sector. However, the positive results of these reforms still have to wait.The further development of the rural settlement network will depend to a large extent on the successful decentralization of power, the completion of the process of creating and organizing the work of rural joint territorial communities.

\section{References}

[1] Lupenko, Yu.O. \& Kropyvko, M.F. (Eds.) (2017). Ahrarnyi ustrii Ukrainy : naukove vydannia [Agrarian system of Ukraine: scientific publication]. Kyiv: NNTs „IAE” [In Ukrainian].

[2] Babinova, O.O. (2011). Derzhavna rehionalna polityka i rehionalnyi rozvytok: suchasni realii Ukrainy ta yevropeiskyi dosvid [State regional policy and regional development: modern realities of Ukraine and European experience]. Kyiv: Feniks [In Ukrainian].

[3] Batanov, O.V. (2010). Munitsypalna vlada v Ukraini: problemy teorii ta praktyky : monohrafiia [Municipal authorities in Ukraine: problems of theory and practice: monograph]. Kyiv: Yuryd. dumka [In Ukrainian].

[4] Borodina, O.M. \& Prokopa, I.V. (2014). Ahrarnyi rozvytok i samorozvytok hromad: modernizatsiia cherez vzaiemnu adaptatsiiu (teoretyko-metodolohichnyi aspekt) [Agrarian development and self-development of communities: modernization through mutual adaptation (theoretical and methodological aspect)]. Ekonomika Ukrainy, 4, pp. 55-73 [In Ukrainian].

[5] Vasylenko, O.P. \& Diachenko, M.I. (2018). Detsentralizatsiia vlady i yii naslidky dlia hromady [Decentralization of power and its consequences for the community]. Retrieved from: http://www.dy.nayka.com.ua/pdf/4_2018/36.pdf [In Ukrainian].

[6] Hladka, T.I. (2015). Detsentralizatsiia vlady v Ukraini yak zasib posylennia demokratii ta pidvyshchennia yii stabilnosti [Decentralization of power in Ukraine as a means of strengthening democracy and increasing its stability]. Derzhavne upravlinnia: udoskonalennia ta rozvytok, 12. Retrieved from: http://www.dy.nayka.com.ua/?\%20op=1\&z=937 [In Ukrainian].

[7] Dzerkalo tyzhnia [Mirror of the week]. (2018). 11 [In Ukrainian].

[8] Dzerkalo tyzhnia [Mirror of the week]. (2018). 16 [In Ukrainian].

[9] Dzerkalo tyzhnia [Mirror of the week]. (2018). 50 [In Ukrainian].

[10] Zhuk, V.M. (2017). Obih zemel silskohospodarskoho pryznachennia v selozberihaiuchii modeli ahrarnoho ustroiu Ukrainy : naukova dopovid [Turning of agricultural lands in a rural-preserving model of the agrarian system of Ukraine: a scientific report]. Kyiv: NNTs „IAE” [In Ukrainian].

[11] Konstytutsiia Ukrainy [Constitution of Ukraine]. Retrieved from: http://zakon3.rada.gov.ua/laws/show/254\%D0\%BA/96$\% \mathrm{D} 0 \% \mathrm{~B} 2 \% \mathrm{D} 1 \% 80$ [In Ukrainian].

[12] Kosach, A.O. (2016). Teoretychni aspekty vplyvu protsesiv detsentralizatsii na ekonomichnyi rozvytok krainy [Theoretical aspects of the influence of decentralization processes on the country's economic development]. Aktualni problemy ekonomiky, 8, pp. 16-21 [In Ukrainian].

[13] Pro vnesennia zmin do deiakykh zakoniv Ukrainy shchodo statusu starosty sela, selyshcha : Zakon Ukrainy vid 09.02.2017 r. № 1848-Ush [On amendments to some laws of Ukraine regarding the age of the village, settlement: Law of Ukraine of 09.02.2017, No. 1848-US]. (2017). Holos Ukrainy, 45 [In Ukrainian].

[14] Pro vnesennia zmin do deiakykh zakonodavchykh aktiv shchodo orhanizatsii provedennia pershykh vyboriv mistsevykh rad ta silskykh, selyshchnykh, miskykh holiv : Zakon Ukrainy vid 04.09.2015 r. № 676 [On amendments to certain legislative acts concerning the organization of the first elections of local councils and village, town and city mayors: Law of Ukraine dated 04.09.2015, No. 676]. (2015). Holos Ukrainy, 06.10.2015 [In Ukrainian].

[15] Pro vnesennia zmin do Konstytutsii Ukrainy (shchodo detsentralizatsii vlady) : Zakon Ukrainy vid 31.08.2015 r. № 2217 a [On amendments to the Constitution of Ukraine (regarding decentralization of power): Law of Ukraine dated 31.08.2015, No. 2217a]. Retrieved from: http://w1.c1.rada.gov.ua/pls/zweb2/webproc4_1?pf3511=55812 [In Ukrainian].

[16] Pro dobrovilne obiednannia terytorialnykh hromad : Zakon Ukrainy vid 05.02.2015 r. № 157-UPI [On voluntary association of territorial communities: Law of Ukraine dated 05.02.2015, No. 157-UPI]. Retrieved from: http://zakon0.rada.gov.ua/laws/show/157-19 [In Ukrainian]. 
[17] Pro zasady derzhavnoi rehionalnoi polityky : Zakon Ukrainy vid 05.02.2015 № 156-UIP [On the principles of state regional policy: Law of Ukraine dated 05.02.2015, No. 156-UIP]. Ofitsiinyi sait Verkhovnoi Rady Ukrainy. Retrieved from: https://zakon.rada.gov.ua/laws/show/156-19 [In Ukrainian].

[18] Pro mistseve samovriaduvannia v Ukraini : Zakon Ukrainy vid 02.05.1997 r. № 280/97-VR [On local self-government in Ukraine: Law of Ukraine dated 02.05.1997, No. 280/97-BP]. Retrieved from: http://zakon1.rada.gov.ua/laws/show/280/97\%D0\%B2\%D1\%80/print1394882263968161 [In Ukrainian].

[19] Pro poriadok formuvannia stratehii obiednanykh terytorialnykh hromad : Postanova Kabinetu Ministriv Ukrainy vid 11.11.2015 r. [On the procedure for formation of strategies for united territorial communities: Resolution of the Cabinet of Ministers of Ukraine dated 11.11.2015] [In Ukrainian].

[20] Pro spivrobitnytstvo terytorialnykh hromad : Zakon Ukrainy vid 17.06.2014 r. № 1508-VII [On cooperation of territorial communities: Law of Ukraine dated 17.06.2014, No. 1508-VII]. (2014). Holos Ukrainy, 23 [In Ukrainian].

[21] Pro skhvalennia Kontseptsii reformuvannia mistsevoho samovriaduvannia ta terytorialnoi orhanizatsii vlady v Ukraini : Rozporiadzhennia Kabinetu Ministriv Ukrainy vid 01.04.2014 r. № 333-r [On approval of the concept of reforming local self-government and territorial organization of power in Ukraine: Order of the Cabinet of Ministers of Ukraine dated 1.04.2014, No. 333-p]. (2014). Uriadovyi kurier, 11 kvitnia [In Ukrainian].

[22] Pro skhvalennia Kontseptsii rozvytku silskykh terytorii : Postanova Kabinetu Ministriv Ukrainy vid 23.09.2015 r. №995-r [On approval of the Concept for rural development: Resolution of the Cabinet of Ministers of Ukraine dated 23.09.2015, No. 995-p]. (2015). Uriadovyi kurier [In Ukrainian].

[23] Rarok, L.A. \& Rarok, O.V. (2015). Merezheva model - prohresyvna forma upravlinnia sotsialno-ekonomichnym rozvytkom silskykh terytorii $\mathrm{v}$ umovakh detsentralizatsii vlady [Network model - progressive form of management of socio-economic development of rural areas in conditions of decentralization of power]. Zbirnyk naukovykh prats Podilskoho derzhavnoho ahrarno-tekhnichnoho universytetu, pp. 228-240 [In Ukrainian].

[24] Lupenko, Yu.O., Kropyvko, M.F., et al. (2014). Rozvytok samorehuliuvannia ta samoorhanizatsii v APK Ukrainy [Development of self-regulation and self-organization in the agroindustrial complex of Ukraine]. Yu.O. Lupenko \& M.F. Kropyvko (Eds.). Kyiv: NNTs „IAE” [In Ukrainian].

[25] Borshchevskyi, V.V. (Ed.) (2012). Rozvytok silskykh terytorii v systemi yevrointehratsiinykh priorytetiv Ukrainy : monohrafiia [Development of rural areas in the system of European integration priorities of Ukraine: monograph]. Lviv: In-t rehionalnykh doslidzhen [In Ukrainian].

[26] Sabluk, P. (2006). Rozvytok silskykh terytorii - zaporuka vidrodzhennia ahrarnoi Ukrainy [Development of rural areas - a pledge of the revival of agrarian Ukraine]. Visnyk ahrarnoi nauky, 5 pp. 21-23 [In Ukrainian]

[27] Borodina, O.M., Prokopa, I.V., Yurchshyn, V.V., et al. (2012). Sotsioekonomichnyi rozvytok silskoho hospodarstva i sela: suchasnyi vymir [Socioeconomic development of agriculture and rural areas: a modern dimension]. O.M. Borodina (Ed.). Kyiv: In-t ekon. ta prohnozuv. [In Ukrainian].

[28] Lupenko, Yu.O., Malik, M.Y., Bulavka, O.H., et al. (2013). Stratehichni napriamy staloho rozvytku silskykh terytorii na period do 2020 roku [Strategic directions of sustainable development of rural territories for the period till 2020]. Yu.O. Lupenko \& O.H. Bulavka (Eds.). Kyiv: NNTs „IAE” [In Ukrainian].

[29] Pavlyk, A.P., et al. (n.d.). Terytorialna hromada yak bazova lanka administratyvno-terytorialnoho ustroiu Ukrainy: problemy ta perspektyvy reformuvannia [Territorial community as the basic link of the administrative-territorial structure of Ukraine: problems and perspectives of reformation]. Retrieved from: http://www.niss.gov.ua/content/articles/files/ADTeritor_alna-gromada-103fe.pdf [In Ukrainian].

[30] Malik, M.Y., Shpykuliak, O.H., Riabokon, V.P., et al. (2017). Formuvannia sotsialnoho kapitalu v instytutsiinomu mekhanizmi ahrarnoho rynku [Formation of social capital in the institutional mechanism of the agrarian market]. Kyiv: NNTs "IAE" [In Ukrainian].

[31] Sharov, Yu.P. \& Sukhinin, D.V. (2008). Munitsypalni posluhy: shliakh do vysokoi yakosti : monohrafiia [Municipal services: the path to high quality: a monograph]. Melitopol: VD MMD [In Ukrainian]

[32] Shpykuliak, O.H. (2009). Instytutsii ahrarnoho rynku : monohrafiia [Agrarian market institutions: monograph]. Kyiv: NNTs „IAE” [In Ukrainian].

[33] Shumliaieva, I.D. (2013). Funktsionalna kharakterystyka diialnosti terytorialnykh hromad [Functional characteristics of the activity of territorial communities]. Aspekty publichnoho upravlinnia, 2 (2), pp. 83-89 [In Ukrainian].

[34] Lemann, N. (2005). The myth of community development. New York Times Magazine, Jenuary 9 [In English].

[35] “2000”, 25.01.2019 [In Ukrainian].

[36] “2000”, 28.12.2018 [In Ukrainian].

[37] “2000”, 16, 20.04.2018 [In Ukrainian].

[38] "2000", 35, 13.10.2017 [In Ukrainian].

[39] “2000”, 41, 10.11.2017 [In Ukrainian]. 